Ocula ${ }^{15}$

Commemorating Charles S. Peirce (1839-1914):

interpretive semiotics and mass media

A cura di Giampaolo Proni e Salvatore Zingale

Novembre 2014 I www.ocula.it - DOI: 10.12977/ocula35

\title{
Some peircean approaches to organizational communication Formal and informal relations in a museum
}

\author{
Carlos González Pérez \\ Universidad Nacional de Jujuy - UNIHR-ISHIR-CONICET \\ carlosfgonzalezp@yahoo.com.ar
}

\begin{abstract}
The main objectives of this work point to an analysis of internal communication processes of a natural science museum of the city of La Plata (Buenos Aires province) to explain the relationship between the formal and informal instances from some approaches to the Peircean semiotics perspective. Other experiences are also taken into account in order to consider different ways of museum's materialization. We believe that the contribution of this semiotic view is enriching because of its triadic sign scheme and because it allows to regard nonlinear complex processes related to the cultural aspects of museums, determined by a given historical moment. The research in the theoretical directions of the authors who are included in this perspective, enables us to approach the complexity of communication processes, given that all communication is done through signs, and signs can be interpreted in one or another way and can grow and generate a more developed set of signs.

We resort to specific operations of visual image semiotics to analyze the signaling in museums, and to specific operations of symbolic semiotics to analyze the discourse of interviews. Through these operations we can achieve explanations about what kind of valuation does the museum's stuff perform about the formal communication processes and also as to the informal spaces which complement them. We can also state that some problems in the organizational structure must be resolved (as an important segmentation identified in the named museum) in order to implement a participative communication model. We identify some aspects related to extension strategies, to the studies of public, and to the relationship that the museum at study has with Argentine aboriginal communities, and likewise aspects that the organization values in the present and wants to project into the future.
\end{abstract}

\section{Keywords}

Formal, Informal, Museum, Organizational communication, Semiotics

\section{Contents}

1. Introduction

2. Interpretation in organizations

3. Iconic semiotics in the study of the organizational semiosis

4. Symbolic semiotics in the study of the organizational semiosis

5. Conclusions

References 


\section{Ocula $a^{15}$}

Commemorating Charles S. Peirce (1839-1914): interpretive semiotics and mass media

Carlos González Pérez, Some peircean approaches to organizational communication

\section{Introduction}

In this work we move towards a proposal to approach the communication in organizations, from the revision and application of semiotic operations with strong Peircean influence. We retake aspects of our research made in a natural science museum of the city of La Plata (Buenos Aires) between 2010 and 2013 (González Pérez, 2013). The main objective of this research is to analyze the internal communication processes of the museum in order to explain the relationship between its formal and informal instances. Another objective is to develop the methodology with Peircean approach. This semiotic view is enriching because of its triadic sign scheme and because it allows to take into account nonlinear complex processes related to the cultural aspects at a given historical moment of the organization being studied. This perspective permits to address different issues related to communication in all its complexity, focusing on the particular problems of any process of interpretation and production of signs, whose diverse possibilities of interpretations may make them grow and generate more developed sets of signs.

We focus on the semiotic analysis because of its methodological interest, in order to emphasize the operations and the kind of explanations they enable, rather than on the analysis of cases. So we do not include a description of the organization of the museum as a case study (and we would not be able to include it in this short space). We will just say that is a natural science museum, managed by a Public University from which it depends for the decision making. As an organization, this museum is very complex because of the diversity of activities carried (investigation, education, museography, conservation, etc.) and for the number of people involved (over five hundred), organized in different areas with specific functions: direction, communication, conservation and exhibition, design and visual communication, audiovisual media, educational area and scientific diffusion, historical archive. This is complemented with various scientific divisions as anthropology, archaeology, ethnography, mineralogy and petrology, geology, phycology, zoology, paleontology, among others. It has twenty one permanent exhibition rooms. It is a complex centenary building: four floors and a mezzanine floor, with exhibition spaces, laboratories, offices, library, workshops, warehouses and ancillary services.

But other cases are also considered in the application of semiotic operations. The methodology we introduce here has its main background in a previous research (González Pérez, 2007) developed in a museum and cultural center of San Salvador de Jujuy city (in the northwest of Argentina). Its internal organization is smaller than the one of La Plata's museum, but it has similar communicational problems related to the museological specificity. Here we address the relation between formal and informal communication but from one particular semiotics, namely, symbolic semiotics.

An ongoing research (González Pérez, 2014b) continues the exploration of the aspects that we present here. It tries to identify how the concepts of semiotic construction of access and inclusion have been made in some anthropological and archaeological museums in the Argentinian northwest. Three different museums from Jujuy, Salta and Tucumán provinces, are 


\section{Ocula $a^{15}$}

Commemorating Charles S. Peirce (1839-1914): interpretive semiotics and mass media

Carlos González Pérez, Some peircean approaches to organizational communication

considered for a semiotic analysis of museological aspects related to iconic and symbolic semiotics. The research began with the exploration of the museological message actualization of some exhibition rooms of a museum of Salta Province that preserve naturally mummified human remains (by freezing). The message presents some features in the way in which it actualizes access. Semiotic analysis (symbolic semiotic) shows contradictions in the verbal discourse (González Pérez, 2014b). The museum was built to preserve three mummies, and its collection is composed by 146 different objects belonging to them.

These museums given as reference, have different scopes, dimensions and materialities, but the anthropological and archaeological heritage they harbor is a common factor. The main objective of the present research, consists in completing the theoretical and methodological proposal, and deepening iconic and symbolic semiotics.

There is a transverse concept: organizational semiosis (González Pérez, 2012). We understand semiosis as Peirce did: “[...] by 'semiosis' I mean, on the contrary, an action, or influence, which is, or involves, a cooperation of three subjects, such as a sign, its object, and its interpretant, this tri-relative influence not being in any way resolvable into actions between pairs." (CP 5.484 ). Our interest is in the production of the semiosis in organizational contexts, like for instance museums.

Some basic aspects for the developing of specific operations are proposed. We explain their relevance and the kind of explanations that they allow to reach, taking into account as a principal aspect what kind of valuation is performed by the personnel in the formal and informal communication processes.

\section{Interpretation in organizations}

When we take into account how production, interpretation and transformation of significations occur in a concrete and specific context, like a specific organization $^{2}$, we may ask: What function can semiotics fulfill? What will be its contribution? How could specific organizational semiotic operations be developed?

A researcher interested in the study of a phenomenon related to an organization, will address a range of manifestations produced in a bounded domain and in a time that is contemporary to his/her intervention. An organization produces a set of communication materials which are intended to be interpreted more or less immediately, especially if such communications are related to its internal organization.

From an analysis of the sign, it can be argued that its production will involve the ground, which is transmitted by a representamen for an interpretant, in a given historical moment of a given society (organizational context, for example, with a definite amplitude). The research about these phenomena

1 We use the habitual way to refer to the Collected Papers (CP) of Peirce, where the first number corresponds to the volume (4) and the second, to the paragraph (536).

2 With the possibility of being traversed by different institutional features (if we follow Schvarstein, 2006) 


\section{Ocula $a^{15}$}

Commemorating Charles S. Peirce (1839-1914): interpretive semiotics and mass media

Carlos González Pérez, Some peircean approaches to organizational communication

could be realized in a time more or less contemporary to the current ways of producing and interpreting those semiosis. But in this process, time has elapsed and things have happened. For Magariños (2008:405):

In this constructive interaction [in reference to thought, semiosis, world as the three minimal elements that comprise the ontological identification of a subject] the transformation of each of the 3 elements is constant, so that any attempted identification is instantaneous and already historical, barely enunciated. The dynamic of interrelations can be described, projecting it to its immediate future transformation, or retrieving it from the immediate fulfilled transformation, but never can it be stated as occurring because the moment it has been enunciated, it becomes a different one as a direct consequence of such enunciation. (Translation belongs to Winchkler ${ }^{3}$ ).

In this short semiotic history (in the few weeks that an organizational diagnostic can be made, or in the very short period that the writing of this paragraph took us), time has passed, and the possibility of the transformation of the current significations has been incorporated. Immediately enunciated, the referred phenomenon (the organizational diagnostic or the quotation of Magariños) is not the same.

The operation of interpreting related to organizational communication phenomena will also consist in describing the behaviors involved in that interpretation, and in explaining the intervention and results of those behaviors. If we consider the communication of a specific organization, the interpretation will be realized through whatever is proposed to an addressee, from images, objects and behaviors, and words (written and in oral manifestation), or combinations of them. The researcher of the communication of an enterprise, of a governmental institution, of a museum, or of any organization, should make an approach to the description and understanding of the objects (in reference to a conception close to the idea of the Peircean dynamic object) that motivates, in Peirce's words, the current creation of signs in that determined organization, in a specific moment ( $\mathrm{CP} 4.536)$. The interpretation in organizations will be related to approaching the semiotic possible worlds, from an organizational phenomenon (their communication, for example). Iconic, indexical and symbolic texts production or those generated through their combination, involve interpretation in different aspects: who produces interprets and so does the addressee of it:

There is interpretation (1) in the producer of a text which has as referent a given entity of the environment and which is intended to establish the signification of such entity so it can be perceived as ontological existent. There is interpretation (2) in the person who interprets that text assigning an effective signification to that entity. There is interpretation (3) in the person who perceives that entity as bearer of the signification attributed to it by that text. (Magariños de Morentin, 2008:165)

3 As "Semiótica de los bordes" is in Spanish, we'll refer, henceforth, to "Semiotic of edges" every time we quote that text. Its translation has been in charge of Phd Giovanna Winchkler in 2011. 


\section{Ocula $a^{15}$}

Commemorating Charles S. Peirce (1839-1914): interpretive semiotics and mass media

Carlos González Pérez, Some peircean approaches to organizational communication

Magariños goes on with an interpretation (4) to consider other significations competing with the previous ones. We propose to add another interpretation: that which is produced by the researcher about those interpretations. In our case, it would be about our interpretations produced about the interpretations that the museum's staff produces about their communication and their organizational problems.

Although it is being realized in the context of the same society and in the same moment, research about communicational phenomena should intend to explain these phenomena, by developing hypotheses because as time passes, phenomena change. A research with these features could explain the variation of semiosis, the discursive hegemonies at time of study, the emergence of new edges in the enunciative forms, and the possibility that a manifestation be not in force (Magariños de Morentin, 2008:420-425). Interpretation in the organizational communication studies should not be but the development of hypotheses.

This pose is close to the idea of sign growth, also developed by Peirce. In relation to museums, but focusing on the problems of exhibitions rooms, Dorsett (2010) argues that the incorporation of artists to the curatorial team generates disjunctions, and their intervention can produce re-meaning, which is essential for the growth of signs. As interpretation is related to the production of interpretants, and as these interpretants are more developed signs, signs grow. We will return to this idea in the section four of this paper.

We understand that research in social disciplines and in humanities should try to approach the explanation of the operation of the dynamic object (without prejudice to the importance of the interpretants production), because it involves what is external to the sign, but has "motivated" (driven, inspired) its production, taking into account the interpretative possibilities (generation of possible interpretants) of every given moment that is intended to be studied. The interpretation in these cases will not be but the development of hypotheses.

The understanding of the interpretative operations in organizations and the need of approaching the dynamic objects, allows us to establish the first step in the study of those semiosis. We mean by semiosis a complex system of signs (Magariños de Morentin, 2008:50), constituted by icons, indexes, symbols or their possible combinations, from which members of an organization construct semiotic expressions, through which they shape their environment. Those semiotic expressions are materialized in organizations, so we call "organizational semiosis" (González Pérez, 2012) the system that facilitates their construction.

Our approach to organizational semiosis and our reflections on the interpretation in organizations lead us to focus on the specific operations needed to get the explanation of such semiosis. We propose operations of visual (or iconic) semiotics and of symbolic semiotics for the study of organizational semiosis.

\section{Iconic semiotics in the study of the organizational semiosis}

One first group of operations that allow an approximation to organizational semiosis, and to the dynamic objects that motivate them as materialization of any message, is conformed by those of the visual or iconic semiotics, for 


\section{Ocula $a^{15}$}

Commemorating Charles S. Peirce (1839-1914): interpretive semiotics and mass media

Carlos González Pérez, Some peircean approaches to organizational communication

the analysis of the images production in an organization. In terms of internal communication, signaling is the strongest related aspect. By organizational signaling we understand a set of visual material images that guide any behavior in the organization context. So they are governed on the basis of the production of new knowledge, using others that the producers of these messages assume as existing in the associative memory of the interpreter. Those material images are constituted by analytic components with high conventionalization; they correspond to the material visual conceptual images, or, to be specifically Peircean, with iconic legisigns (CP 2.258).

We have already quoted the triadic concept of sign. Now we are interested in what is specifically related to the image, to the form, and this is a firstness, so that we will talk mainly, but not only, of icons: "Firstly, there are likenesses, or icons; which serve to convey ideas of the things they represent simply by imitating them" (EP 2:54).

Magariños de Morentin (2005, 2007, and 2008) took up the Peircean proposal, and by the incorporation of other points of view he developed specific operations for the study of the semiotics of the image, or iconic semiotics. He constantly has paid attention to the need for relevant operations in order to explain the way signification is produced from images. In this sense he gets in line with the requirements that Groupe $\mu$ lays down for a specific semiotic of image. His work incorporates cognitive aspects from referents such as Marr (1982) and Kosslyn (1996), among others.

In iconic semiotics the sign has "[...] the quality of arousing in a mind the possibility of being considered as substituent of other form which is not the one being perceived" (Magariños de Morentin, 2008:220). We are interested in images that accomplish this function, for what they can be considered as substituent semiosis. In this case the sign configuration will be: "(something) a visual perception proposal, (in some respect or capacity) considered as representation, (for something) intended to configure a form, (to somebody) for its valuation by the perceptor" (Magariños de Morentin, 2008:220).

The approach and analysis instances of interpretations produced by material visual images, following Magariños (2008:223-235), are in relation to identification, recognition and interpretation. A concrete application of these operations on a specific corpus can be found in González Pérez, 2013 y $2014 a^{5}$.

\subsection{Identification}

Material visual images can be constituted to show: qualities, existents, norms or the combination of two or three of these aspects (which is the most common). But in the consideration of the predominance of one of them, the

4 Now we use the habitual way for referring to The Essential Peirce: Selected Philosophical Writings (EP). The first number indicates volume (2 in this case) and the second is the number of the page (5).

5 In relation to exhibition rooms, and the use of diagrams, McTavish (2013:5455) has also explored the Peircean perspective, but his interest, unlike ours, lies in the way materialities in a museum enable possibilities in the world observation. 


\section{Ocula $a^{15}$}

Commemorating Charles S. Peirce (1839-1914): interpretive semiotics and mass media

Carlos González Pérez, Some peircean approaches to organizational communication

identification of three different material visual images can be taken into account: plastic, figurative, conceptual.

Material visual plastic image (iconic qualisign, CP 2.254) shows pure visual qualities (color, texture, or form). Material visual figurative image (iconic sinsign, CP 2.255) shows some analogies with an existent. Material visual conceptual image (iconic legisign, CP 2.258) involves regulated forms (or the incorporation of the social convention to the image), known as well as replicas. As we are in front of the codification of laws and norms, their being in force must be taken into account, in a determined moment of a given society.

In the case of images that are part of the signaling system of a given organization we can say that we are in front of material visual conceptual images, as the showing of a suggestion, an indication, a prohibition, etc. is what is predominant in them. While they could incorporate photographs that can be considered specifically as identifying existents (as figurative images), icons incorporating regulation could also be identified (such as words, arrows, a circle with a line crossed that in our culture -occidental, Argentine- actualizes something forbidden). Color ranges could also be identified, as in the identification of spaces in a plan. Altogether, these images and other strictly symbolic elements (as words, arrows, etc.) suggest a route, advice to pay attention to certain objects, or even prohibit. That is why we argue that the conceptual feature is prevailing.

\subsection{Recognition}

In the instance of recognition the constitutive components of images are specified. These components can actualize attractors. The concept of attractor is related to the visual memory, in the sense that it is conformed by determined mental representations stored in the "associative memory" (Kosslyn, 1996:215), which are actualized with the perception of the material visual image proposed. For Magariños (2008) is a set of forms organized with certain constancy, for what one can talk about its being in force (contextual, for a given society in a determined time), since some attractors can lose their validity in other determined moment.

In the case of qualitative or plastic perceptual proposals, abstractive attractors are actualized: the qualia are related to the individual experience, they are the constructive analytic components of these images, and are produced without rules or specifics laws (CP 6.222; CP 6.225; Magariños, 2008).

For existential or figurative perceptual proposals, and following the specificity requirements of each image, recognition of these images is proposed from the configuration of existential attractors. It is considered that the figurative images representation is based in analog recognition processes. These attractors are actualized as analytic components such as: marks, axes and occlusion contours (Groupe $\mu$, 1993; Magariños de Morentin, 2008; Marr, 1982). They are considered as perceptual components that configure a shape by inside and outside grouping.

Axes establish information for recognizing the objects shape from their spatial arrangement (axes distribution, inclination angles with respect to the main axis, Marr, 1982), their orientation, and relative size. 


\section{Ocula $a^{15}$}

Commemorating Charles S. Peirce (1839-1914): interpretive semiotics and mass media

Carlos González Pérez, Some peircean approaches to organizational communication

In his studies of vision, Marr (1982) asks himself about how contours of a monocular image can transmit non ambiguous information about a shape: "[...] is simply a contour that marks a discontinuity in depth [...]" (Marr, 1982:218). This contours enable depth representation in a two dimensions image, every time a contour appears in front of something, what can be determined by its occlusion function of what we cannot see (it remains occluded by that contour).

Regulated or conceptual perceptual images enable the actualization of a different attractor, that Magariños has named symbolic. These images are constituted by the incorporation of social convention (a regulation or a law) to the image. They are iconic legisigns, and for being interpreted the interpreter should have previous knowledge, social and in force, for their correct decoding. Symbolic attractors are organized in a virtual system, and therefore they have the character of types: "These and their appropriate system preexist, as preconfigured stereotypes, in the social field of the interpreter." (Magariños, 2008:226). The being in force of these attractors is considered again, but this time as symbolic because of the mental operations involved. The interpretation is determined by a given moment in a given society. They have a narrow freedom to vary, and they are constituted by a minimum number of parts. The constructive analytic components of these images are taken by Magariños from the Cátedra Fontana (1996:40): the support structure and the morphology.

In the case of images that conform the signaling system of an organization, we can identify plastic aspects (colors, lines, images quality, gradients, grayscale, etc.) that can actualize plastic attractors (qualia), figurative attractors (through photography, for example) which refer to the shape of existents stored in interpreter's memory actualizing existential attractors, but also symbolic attractors because they refer to types that occupy a place in a system. Because of the mental operation that these images involve for their interpretation, we argue that what prevails is social convention, as what they pursue is to show the place in the system that the considered types occupy. But also, what these images generate semantically is an effect of meaning that involves consequences in action: suggest, deny, etc.

\subsection{Interpretation}

As a third point, Magariños proposes to take the effect of meaning that allows to update a material visual image which, in relation to other valid semiosis (determined by a specific time and society), will enable the appearance of the interpretative discourses. Those semiosis are important too, as no one can be enough for interpretation by itself. This is the reason why material visual images do not signify by themselves, but produce a demonstration effect.

In each case (plastic, figurative or conceptual images) the demonstration effect is related to the actualization of the corresponding attractor and the way it remains configured for perception, which can be given in an interpretation level or in a creative effectiveness level.

In the case of plastic images, if the researcher demonstrates the preexistence of an abstractive attractor (quale-qualia) in the interpreter's memory, 


\section{Ocula $a^{15}$}

Commemorating Charles S. Peirce (1839-1914): interpretive semiotics and mass media

Carlos González Pérez, Some peircean approaches to organizational communication

from which relationship will extract the actual meaning, he could demonstrate their interpretative effectiveness. If, on the other side, shows the lack of this attractor (lack of experience of this private sensation) in the interpreter's memory, the researcher could demonstrate their creative effectiveness.

If the research demonstrates the preexistence of an existential attractor in the interpreter's memory from which relationship will extract the actual meaning, he could demonstrate the interpretative effectiveness of figurative images. But if the researcher shows the existence of a relationship of similarity/difference of an existential attractor (as a dynamic mnemonic image) available in the interpreter's memory, he could demonstrate the creative effectiveness of that image.

Finally, and about conceptual images, if the researcher demonstrates the preexistence of a symbolic attractor in the interpreter's memory, from which relationship will extract the actual meaning, he could demonstrate their interpretative effectiveness. The creative effectiveness of the image could be considered if the researcher can demonstrate the place of the appropriate system of visual perceptions socially ruled where the symbolic attractor is actualized. In order to do this, the attractor should have been previously learned and be available in the given society.

If we imagine an airport's signaling we can recognize some figurative attractors in those images, which actualize different information. Nevertheless the images are not only identifying a particular existent, but also are fulfilling other functions: they are identifying a place, they explain how to do something, they forbid, etc. The demonstration effect has to do with the place they occupy in a system, that is to say they constitute types, for what they have to be considered as conceptual images.

\section{Symbolic semiotics in the study of the organizational semiosis}

Other possibility of approximation to organizational semiosis is the development of interviews, which allows to materialize some discourses referred to different organizational problematic and to generate information about the research objectives. In the case that we are considering for this paper, we had to identify in a museum the relationship between formal and informal communication, and to explain the valuations that the personnel, involved in different institutional activities, makes about that relationship. We will not develop the ethnographic aspects of the research because of the $d$ space, but we will focalize (as we did before) on the semiotic operations that enabled those interviews' analysis and, specially, the kind of conclusions that this analysis allowed us to reach.

We are taking into account another particular semiotics, proposed by Magariños (2008), that involves specific operations for discourse analysis: symbolic semiotics. This particular semiotics explains the significations assigned to determined social phenomenon "when its representation/interpretation has been socially produced by symbolic texts" (Magariños, 2008:172). The reference to Peirce's work is also clear, as for him a symbol is "a conventional sign, or one depending upon habit [...]" (EP 2:9). He also called the 


\section{Ocula $a^{15}$}

Commemorating Charles S. Peirce (1839-1914): interpretive semiotics and mass media

Carlos González Pérez, Some peircean approaches to organizational communication

symbols "general signs", "which have become associated with their meanings by usage" (EP 2:5).

From a Peircean point of view, by symbolic texts we can consider those that have been produced, mainly but not exclusively, by speech, and the signs where the conventional aspect is predominant, for what they require an important formalization (which implies the existence of stable and identifiable rules). Is through this kind of signs that we can build other signs, be aware of abstract relations and spread ideas. This can be made by the written word, or by spoken language (as words, for example). Peirce himself used words as examples of symbols:

Any ordinary word, as "give", "bird", "marriage", is an example of a symbol. It is applicable to whatever may be found to realize the idea connected with the word; it does not, in itself, identify those things. It does not show us a bird, nor enact before our eyes a giving or a marriage, but supposes that we are able to imagine those things, and have associated the word with them." (EP 2:9).

If we consider these relations in an organization, and about its internal communication as given in a museum, we can think about this kind of signs as a way of understanding the organizational representations, available for the analysis in the materialized discourse: the one produced by the interviews. The conventional aspect, as a specific acquired knowledge of codes, is required. So a discourse would be able to be understood for a specific community in a given time (a group of people that in given moments shares the knowledge of that code).

From a very similar perspective, but in order to analyze meaning-making in art museums, Dorsett (2010) develops the Peircean perspective, and thinks about these very same relations and the possibility of sign's growth, the cross-semiotic transaction and the idea of agent of change. Among other aspects, iconicity of the artist is taken into account, as it drives to re-meaning the art proposal, in relation to the production of interpretants, with the possibility to think about unlimited semiosis and the growth of symbols. In our case, we may not think about the public interpretations, but about those produced by people working in a museum. The analysis of symbols, in this way considered, could explain how the internal community of a specific museum represents its own problems (in specific relation to communication), and as the symbols grow in use and in experience (EP 2:10), this transformation can also be identified.

We are not arguing that symbols do not have iconic or indexical aspects, or that the relation between them cannot be proposed. As Peirce clarifies: "In all reasoning, we have to use a mixture of likenesses, indices, and symbols. We cannot dispense with any of them. The complex whole may be called a symbol; for its symbolic, living character is the prevailing one.” (EP 2:10). As the interest is the development of specific operations for symbolic signs analysis, what is in predominance here are the symbolic aspect of the signs; this situation enables the possibility (in a very concrete way for Magariños, 2008) of the consideration of another specific semiotics: symbolic semiotics. This method- 


\section{Ocula $a^{15}$}

Commemorating Charles S. Peirce (1839-1914): interpretive semiotics and mass media

Carlos González Pérez, Some peircean approaches to organizational communication

ological proposal does not start from the development of a priori categories, but from concepts that have to do with the research objectives (museum and communication in our case) to analyze the discourses to establish how those concepts are defined by the interviewed, and to show how they are related in the concrete use: approaching, differentiating, contradicting, or refusing each other.

Some Foucault's (2004) postulates are recovered by Magariños for the epistemological sustenance of this proposal. The concept of "uttering" is taken into account because is the speech what constructs the meaning of what is referred. The maintenance or the change in the use of rules involved in their production is fundamental for the identification of the "discursive formations" (Foucault, 2004:62) in force in a determined historical moment of a given community "and to attribute, to each of them, their respective effectiveness in the struggle for the hegemonic acceptance of their proposal of attribution of meaning to the environment" (Magariños, 2008:172).

This perspective does not seek to identify the truth of social significations, but to explain the being in force of those significations in a given time of a determined community, based on the assumption of discursive plurality of societies. What is important, then, is the construction of the possible semiotic worlds in force from those discourses regarding the concepts that could be identified in them.

\subsection{Specific operations of the symbolic semiotics}

Once a corpus has been identified and accepted as valid, the application of analytical instruments is necessary. The analysis must show evidence in how the corpus contains the material and conceptual relations that are involved in the social production of the signification of the phenomenon in study. The specific semiotic operations will be applied to this material (Magariños de Morentin, 1998:233-253; 2008:175-185): normalization, segmentation, elaboration of contextual definitions, and the development of axes and sequential and contrasting networks.

Normalization is an operation that allows avoiding or noticing the addition or deletion in misused or truncated terms or expressions, supplementing them syntactically through anaphoric or cataphoric recuperations. Syntactically incomplete constructions are also processed. Metalinguistic graphic marks are used in every case for explicitly identifying the annalist's interventions.

The second operation is segmentation, which consists in disposing the parts of a text that are considered elemental in the construction of meaning. The semantic judgment is not considered here, because it can be misleading and subjective. A syntactic criterion is chosen for being more objective, as it allows taking syntax as the group of relations, necessary but not sufficient, for the construction of the meaning. According to this syntactic segmentation criterion, the beginning and ending of a textual segmentation will be marked, as it contains the base sentence and modalizers.

Each segment will become a contextual definition, through which the sense of a term in that segment is established, in relation to the very context where 


\section{Ocula $a^{15}$}

Commemorating Charles S. Peirce (1839-1914): interpretive semiotics and mass media

Carlos González Pérez, Some peircean approaches to organizational communication

the term appears associated. Different prepositions are used in the contextual definition elaboration, for the syntactical articulation of the rest of the complete textual segment. For example: " $\mathrm{X}$ is [that+that/which+(remainder of sentence context)]" (Magariños, 2008:178).

Contextual definitions can be grouped in different conceptual axes, which allow ordering them in representative categories of the modes of meaning attribution of the corresponding terms. Axes can be developed by the researcher according to the research objectives (Magariños, 1998).

The elaboration of sequential and contrasting networks is the next step in this analysis. They are graphic representations that put different terms or concepts used for the definition of axes and sub-axes, in sequential or contrasting relation. Each axe will contain a group of contextual definitions (previously grouped in this axe). From the relation between the axes, a network can be established, reflecting those relationships, similarities or differences between the other groups of contextual definitions. Network analysis facilitates the approaching to the possible semiotic worlds constructed by the different interpretations/representations of the organization members, about the problematic that is being researched. Some of those interpretations attributed to the phenomenon under study will be consistent with each other, but others, simultaneously, will be alternatives and even contradictories. The significance of the phenomenon or problem that is being studied is explained, as well as the result of the confrontation of the semantic differences of each interpretation.

Possible semiotic world's concept is in close relation to Foucault's "discursive formations". For Magariños (2008:187) is:

[...] the representation of a (non contradictory) set consisting of minimal textual structures, syntactically and semantically complete, constituted by the triadic relation that associates two terms by a given connector, and, if any, by the modifiers that each term and the connector receive, always preserving the initial minimal syntactic structure $[\ldots]$

The triadic aspect considered in the association of terms through a connector can be distinguished in this definition. The previous operations are being focalized here (specially, contextual definitions). In the same part Magariños argues that those minimal textual structures are derived from the corpus, and are related to the hypotheses or the research's objectives. In our concrete investigation we identify the museum's personnel interpretations produced in relation to specific aspects considered in the interviews. As a result we could approach the possible semiotic worlds of the internal communication of the organization in study, starting from the development of two complex networks: 1. Communication network; and 2. Museum network. Due to lack of space we do not incorporate here the complete growth of the networks. Instead of that, we leave raised the operational and theoretical basis for their implementation, and we move forward to some conclusions ${ }^{6}$.

6 In case that the reader requires further information for the application of these operations we suggest to see: González Pérez, 2013; Magariños de Morentin, 1998 and 2008. 


\section{Ocula $a^{15}$}

Commemorating Charles S. Peirce (1839-1914): interpretive semiotics and mass media

Carlos González Pérez, Some peircean approaches to organizational communication

\subsection{Explanations enabled by symbolic semiotics}

The discursive analysis has allowed us to approach the interpretations generated about the museum and its communication, in relation to different processes that are part of the organizational development. The most analytical richness is found in the used methodology. More than a mere description of those processes, it permits the identification of consistent and conflicting interpretations, referred to different valuations of the museum and its communicational problematic, evidencing at least two ideological positions: one official in tune with the current leadership of the organization, and another of opposition. These contradictions have been put in explicit relation; this process has been facilitated by the development of the conceptual and contrasting networks. It is through this working method that we understand the interpretation production context about the phenomenon under study. This logical explanation implies an approximation to the dynamic objects that have motivated the sign production (as we proposed at the beginning of this paper).

One of the most important conclusions has to do with the relationship between formal and informal communication in the organization. The reading of the networks shows that it is clear that this relationship is balanced, given that formal aspects are recognized in the organization structure (the relevance of each area, units and divisions) and in its communication (recognizing old and new formal supports and channels). But informal aspects are also recognized as being highly valued and taken into consideration at the moment when formal aspects do not permit to generate answers for the required activities in relation to the organization's objectives. Informal aspects allow the realization of internal meetings and a set of communications that generate work spaces with rhythms that are better adjusted to personnel's needs. Oral communication is doubly valuated in the studied organization: it allows the message manifestation in a more opened way, with the possibility of incorporating emotive aspects. On the other hand this orality generates interpretative troubles and difficulties.

With this analysis we can argue that the approximation to the processes of internal communication in an organization cannot be realized exclusively through the formal aspects, or exclusively from the informal aspects, as both instances complement themselves. This complementarity is not only given in practice, but is also recognized discursively, holding that the possibilities of what is formally established are used up to their limits, generating other informal spaces to what the formal aspects cannot allow. So, it can be argued that every organization must leave space for the spontaneous and informal as being part of the everyday, because no interpersonal relationship can be expected or mediated through absolutely formalized channels, nor can be studied or understood considering just the formal aspects or just the informal ones.

The instances of ruling and opposition that we have designated before, show a fragmentation in the organization, which can also be interpreted from the formalization of its structure, the place where old scientific departments are located, whereas new units and areas are in another representative instance. If the organization really wants to develop a participative communication model (as is argued in its speech) it should move forward with concrete 


\section{Ocula $a^{15}$}

Commemorating Charles S. Peirce (1839-1914): interpretive semiotics and mass media

Carlos González Pérez, Some peircean approaches to organizational communication

actions in order to reduce that fragmentation, aspect that will impact on its formal structure. The relation between the formal (the structure) and the informal (what happens outside the formal pre-established structure) communication is in evidence again. These are some of its possible repercussions.

The network analysis also evidences a clear intention to deepen the participation of publics in museography topics in the studied museum evaluating the possibility that they could define what to exhibit in the future. To accomplish this is necessary to work strongly in extension as publics need information about the existent heritage in this museum. The study of publics is another activity that this museum has to strengthen, and it is related to extension. Through this sort of studies visitors' origin can be established, as well as their interests, the apprehension levels of the museographic proposal, their doubts and reflections, among other aspects that can be used in the exhibition design experience.

The analysis allows us to say that the museum is properly positioned to a respectful and responsible work with indigenous communities in relation to refund and the removal of human remains from the exhibitions rooms, actions that have been initiated by this organization a few years ago. According to interviews, this museum has removed human remains, but some mummies of different origin can be found in exhibition. This is a discursive contradiction that the organization must solve. A huge contradiction arise if we compare these kind of museological decisions with those prevailing in Salta, where mummies are not in the way of being removed from exhibition or restored to the indigenous communities.

\section{Conclusions}

We have shown what kind of explanations, in relation to organizational communication, we can reach from this semiotic approach. We argue that the study of the organizational semiosis, as defined here, considering how relations between signal entities are given, attending, mainly, to the possibilities of approximation, recuperation or reconstruction of the dynamic object in the organization, can be realized from the application of semiotic operations related to specific semiotics. In this paper we have shown some possibilities from the iconic and symbolic semiotics, but we do not deny the existence of others?

This complete analysis sheds light over the relationship between formal and informal aspects in the communication processes of the considered organizations and it allows achieving specific explanations of the nature that we have set out.

But the potential of this analysis makes us consider other aspects. From the network analysis the relation between present and future of the organization is also raised, considering continuities and discontinuities, which, from the interviewee's thinking (materialized in the discourses), enable the analysis of different processes in an organization which can be put in relation for the

7 Indexical semiotics, from a Peircean perspective, may also be considered in the study of museums, as those developed by Dorsett (2010; 2012), Magariños (2003). 


\section{Ocula $a^{15}$}

Commemorating Charles S. Peirce (1839-1914): interpretive semiotics and mass media

Carlos González Pérez, Some peircean approaches to organizational communication

study of their transformation and the growth of symbols (EP 2:10), as well as the development of an organizational planning related to the interests of the public. Present and future are clues in the consideration of an opening, which if it is articulated with the study of the past, could be used to develop a proposal for the historic-semiotic construction of the organizations.

\section{References}

Cátedra Fontana

1996 Pensamiento tipográfico, Buenos Aires, Edicial.

Dorsett, Chris

2010 "Making meaning beyond display" in S. H. Dudley (ed.) Museum materialities: objects, engagements, interpretations, London and New York: Routledge, pp. 241-59

Dorsett, Chris

2012 "Things and theories: the unstable presence of exhibited objects" in S. H. Dudley [et al.] (eds.) The thing about museums: objects and experience, representation and contestation, London and New York: Routledge, pp. 100-16.

Foucault, Michele

2004 La arqueología del saber, Buenos Aires, Siglo XXI Editores.

González Pérez, Carlos

2007 Para una buena comunicación, lo mejor es empezar por dentro. La comunicación interna en el Centro Cultural y Museo Jorge Pasquini López, Unpublished Thesis, Licenciatura en Comunicación Social, Facultad de Humanidades y Ciencias Sociales, Universidad Nacional de Jujuy.

2012 Itinerario semiótico para el estudio de organizaciones como segundidad, "Diálogos de la comunicación. Revista académica de la Federación Latinoamericana de Facultades de Comunicación Social”, 83, Enero-Marzo 2012, pp: 1-18.

2013 Aplicaciones de la semiótica peirceana al estudio de la comunicación interna organizacional. El caso de las relaciones entre los procesos de comunicación formal e informal en el Museo de La Plata, Unpublished Thesis, Doctorado en Comunicación, Facultad de Periodismo y Comunicación Social, Universidad Nacional de La Plata.

2014a Un abordaje semiótico de la señalización organizacional de un museo argentino: hacia la recuperación de los sistemas interpretativos de las imágenes materiales visuales conceptuales, "Lexia", 17-18, 2014, accepted for publication.

2014b. Acceso e inclusión en los museos: construcción semiótico-histórica de su conceptualización. Aproximación a un museo del Noroeste Argentino, Proceedings of the meeting "7 Congreso Latinoamericano de Semiótica (FELS)”, San Luis Potosí (México).

Groupe M

1993 Tratado del signo visual, Madrid, Ediciones Cátedra.

Magariños de Morentin, Juan

1998 Manual operativo para la elaboración de "definiciones contextuales" y "redes contrastantes", "Signa”, 7, 1998, pp. 233-253.

2003 Hacia una semiótica indicial. Acerca de la interpretación de los objetos y los comportamientos, A Coruña, Edicios do Castro. 
Carlos González Pérez, Some peircean approaches to organizational communication

2005 Performance of abduction in the interpretation of visual images, "Semiotica", $153,1 / 4,2005$, pp. 375-388.

2007 "Los mundos semióticos posibles de las imágenes visuales", in Agüero, R. F., Arrueta, J. C. y Burgos, R. (editores), Sobre Sentidos. Estudios sobre Comunicación, Cultura y Sociedad, Jujuy, Ediunju.

2008 La Semiótica de los Bordes. Apuntes de metodología semiótica, Córdoba, Comunicarte.

2011 Semiotic of edges. Notes on semiotic methodology, translation by Giovanna Winchkler, 2011, vailable in: http://www.semioticmethodology.com/Edges. pdf (accessed May 2014).

McTavish, Lianne

2013 Defining the modern museum. A Case Study of the Challenges of Exchange, Toronto Buffalo London, University of Toronto Press.

Marr, David

1982 Vision. A computational Investigation into the Human Representation and Processing of Visual Information, New York, Freeman and Company.

Kosslyn, Stephen M.

1996 Image and Brain. The Resolution of the Imagery Debate, Cambridge, London, The MIT Press.

Peirce, Charles S.

1931-1958 Collected Papers of Charles Sanders Peirce. Hartshorne, P. Weiss y A. W. Burks (editors), Cambridge, Harvard University Press; MA. Cambridge, The Belknap Press of Harvard University Press.

1992-1998 The essential Peirce: Selected Philosophical Writings. Vol. 2, N. Houser et al. (editors), Bloomington, Indiana University Press.

Schvarstein, Leonardo

2006 Psicología social de las organizaciones. Nuevos aportes, Buenos Aires, Paidós.

Carlos Federico González Pérez, PhD in Communication (Facultad de Periodismo y Comunicación Social, Universidad Nacional de La Plata, 2013). Postdoctoral scholarship holder of the National Council of Scientific and Technical Research (CONICET), Argentina. Director of the research project "Discourse's transformations: semiotic-historical constructions processes in communication, culture and society", and Professor in Communication and Education Seminar, Social Communication bachelor's degree, Universidad Nacional de Jujuy. 